\title{
Sosialisasi Tentang Dampak Putus Sekolah Di Desa Sekotong Timur Lembar Lombok Barat NTB
}

\author{
Saimun \\ Doden Prodi. Pendidikan Matematika, UIN Mataram
}

\begin{abstract}
Abstrak: Sosialisasi dampak putus sekolah di Desa Sekotong Timur Lembar Lombok Barat bertujuan untuk memberikan pemahaman dan pengetahuan akan pentingnya pendidikan formal atau sekolah bagi anak-anak usia sekolah di Desa Sekotong Timur yang telah memutuskan untuk tidak melanjutkan sekolahnya karena berbagai faktor, baik faktor ekonomi, minat anak yang kurang, perhatian orang tua yang rendah, factor budaya, fasilitas belajar kurang, ketiadaan sekolah/sarana, dan cacat atau kelainan jiwa.

Kegiatan sosialisasi ini sangat bermanfaat bagi masyarakat Desa Sekotong Timur, utamanya bagi anak-anak putus sekolah di desa tersebut. Melalui sosialisasi dampak putus sekolah ini, anak-anak di Desa Sekotong Timur diharapkan melanjutkan sekolah atau pendidikan ke tahap selanjutnya sehingga memiliki kecakapan dan pengetahuan yang cukup baik guna meningkatkan tarap sumber daya manusia yang optimal dan mengurangi prosentase jumlah anak yang putus sekolah.

Kegiatan sosialisasi dampak putus sekolah diselengarakan di Desa Sekotong Timur, bertempat di AULA Diniah Miftahul Falah Sekotong Timur Lembar Lombok Barat pada hari Sabtu, tanggal 30 September 2017. Kegiatan ini dibuka dengan sambutan yang disampakan oleh pengabdi dan Bapak Zohri sebagai wakil dari Desa Sekotong Timur. Selanjutnya materi kegiatan sosialisasi dibawakan oleh seorang narasumber dan diakhiri dengan pembentukan tim pendampingan sebagai faktor penguatan keberhasilan dari kegiatan sosialisasi.
\end{abstract}

Kata Kunci: sosialisasi, putus sekolah, usia sekolah.

\section{PENDAHULUAN}

Anak putus sekolah adalah keadaan dimana anak mengalami keterlantaran karena sikap dan perlakuan orang tua yang tidak memberikan perhatian yang layak terhadap proses tumbuh kembang anak tampa memperhatikan hak-hak anak untuk mendapatkan pendidikan yang layak. Bisa juga dikatakan bahwa anak putus sekolah adalah murid yang tidak dapat menyelesaikan program belajarnya sebelum waktunya selesai atau murid yang tidak tamat menyelesaikan program belajarnya.

Masa anak-anak merupakan tahapan penting dalam pembentukan dasardasar kepribadian di kemudian hari, masa untuk berkreatifitas secara konkrit, dimana anak-anak mengembangkan kemampuan menganalisa dan mengelola pola 
relasi sosial dalam hubungannya dengan kemampuan memecahkan berbagai jenis masalah yang dihadapi. Kemampuan tersebut akan berguna bagi hidupnya di kemudian hari.

Di Indonesia ini pemerintah mempunyai program wajib belajar 9 tahun program ini didasari konsep "pendidikan dasar untuk semua" (universal basic education) yang pada hakekatnya berarti penyediaan akses yang sama untuk semua anak. Hal ini sesuai dengan kaedah-kaedah yang tercantum dalam piagam PBB tentang hak azazi manusia, tentang hak anak, dan tentang hak dan kewajiban pendidikan anak.

Faktor penyebab anak tidak dan putus sekolah disebabkan oleh beberapa factor, yaitu ekonomi, minat anak yang kurang, perhatian orang tua yang rendah, factor budaya, fasilitas belajar kurang, ketiadaan sekolah/sarana, dan cacat atau kelainan jiwa. Akibat anak putus sekolah dalam kehidupan sosial ialah semakin banyaknya jumlah kaum pengangguran dan mereka merupakan tenaga kerja yang tidak terlatih. Kenakalan remaja, tawuran, kebut-kebutan di jalan raya, minum minuman keras dan berkelahi, perasaan minder dan rendah diri, banyak orang yang menganggur itu dikarenakan banyak sekali anak yang tidak mempunyai ijazah, maupun tidak adanya pembekalan skiil bagi mereka yang putus sekolah. Tidak adanya kegiatan yang menentu, sehingga kadang-kadang dapat menimbulkan kelompok-kelompok pemuda liar, anak-anak nakal dengan kegiatannya yang bersifat negative seperti mencuri, memakai narkoba, mabukmabukan, menipu, menodong dan sebagainya.

Hasil wawancara dengan Kepala Desa Sekotong Timur yang bernama Haji Ahmad beserta Kepala Karang Taruna yang bernama Dedi Susanto, S.Pd memberikan informasi bahwa banyak anak putus sekolah di desa ini terlebih lagi di desa ini dekat dengan tambang emas tradisional yang mengakibatkan anakanak lebih tertarik menambang emas dibandingkan dengan bersekolah. Menurut informasi beberapa penambang emas bahwa penambangan emas erat banyak sekali dari kalangan remaja usia sekolah. Seiring waktu keadaan tambang emas kurang menguntungkan sehingga mereka mencari jalan dengan menjadi TKI di luar Negeri yang penghasilannya tidak menentu bahkan banyak diantara mereka menjadi TKI gelap sehingga terpaksa dideportasi dan kehilangan pekerjaan. 
Transformasi, Vol. 13, No. 2, Juli 2017:208-218

\section{PEMBAHASAN}

Peserta pada kegiatan " Sosialisasi dampak putus sekolah di Desa Sekotong Timur Lembar Lombok Barat NTB" adalah anak-anak yang berasal dari beberapa Dusun yang ada di Desa Sekotong Timur utamanya yang sedang menempuh sekolahdi tingkat SLTP dan SLTA.

Untuk lebih jelasnya, data peserta yang mengikuti Sosialisasi dapat disajikan pada tabel berikut:

\begin{tabular}{|l|l|l|}
\hline No. & NAMA & Asal Dusun \\
\hline 1 & Ramdhani & Aik Mual \\
\hline 2 & Muhiwan Rozi & Telaga Lindung \\
\hline 3 & Ilman Hanifi & Menomang \\
\hline 4 & Samudin & Jelateng sedenggang \\
\hline 5 & Widia Ningsih & Kambeng Timur \\
\hline 6 & Suriah & Kambeng Timur \\
\hline 7 & Nurma Ningsih & Aik mual Utara \\
\hline 8 & Mariana & Jelateng Timur \\
\hline 9 & Audatul Hidayah & Kambeng Utara \\
\hline 10 & Novi Yulianti & Kambeng Utara \\
\hline 11 & Uswatun Hasanah & Jelateng Timur \\
\hline 12 & Desi Fitriani & Bun Beleng \\
\hline 13 & Muhamad Hirzan & Kambeng Barat \\
\hline 14 & Taufik Febriansah & Kambeng Barat \\
\hline 15 & Muzahar & Kambeng Barat \\
\hline 16 & Nahwi & Menomang \\
\hline 17 & Muhamad Nizam & Bun Beleng \\
\hline 18 & Azam Rafii & Aikmual Utara \\
\hline 19 & Angga Agus Rianto & Jelateng Sedenggang \\
\hline 20 & Zakaria & Aik Mual \\
\hline & & \\
\hline
\end{tabular}


Narasumber pada kegiatan sosialisasi dampak putus sekolah iniadalah Kemenag Wilayah Provinsi NTB Bidang Pendidikan yaitu Bapak H. Muhammad Abu Arif Aini, S.Ag M.Pd

Dalam sosialisasi ini, unsur moderator sangat dibutuhkan untuk menjembatani komunikasi antara narasumber dan peserta dalam sesi diskusi. Hal ini dimaksudkan agar proses diskusi berjalan lebih tertib dan teratur, sehingga setiap pertanyaan yang diberikan oleh peserta mendapat tanggapan atau jawaban yang tepat dari narasumber. Adapun yang bertindak sebagai moderator pada kegiatan ini adalah ibu Hj. Siti Fatmawati, S.Ag, yang merupakan mantan ketua PKK Desa Sekotong Timur Lembar sekaligus mantan istri Kepala Desa Sekotong Timur Lembar Lombok Barat periode 2012-2016 beliau memahami kondisi anak-anak yang ada di Sekotong Timur Lembar Lombok Barat NTB.

Sebelum pelaksanaan sosialisasi dampak putus sekolah di Desa Sekotong Timur Lembar pengabdi melakukan observasi di masing-masing dusun selanjutnya wawancara dan interviu dengan kadus beberapa orang tua dan anak-anak yang ada di masing-masing dusun didampingi oleh pihak dari desa dan ketua KPAD (Kelompok Perkumpulan Anak Desa) sebanyak 5 kali terdiri dari dua dusun setiap sekali kegiatan observasi wawancara dan interviu. KPAD ini salah satu bagian dari aparatur Desa yang bergerak di bidang pencegahan pernikahan dini, penanggulangan kenakalan remaja, penanggulangan penyalahgunaan narkoba serta pendampingannya, pendampingan kepada perempuan korban perceraian dan beberapa kegiatan lainnya.

Hasil observasi, wawancara dan interviu awal sebanyak lima kali ke sepuluh dusun bersama pihak-pihak yang telah dijelaskan sebelumnya maka diperoleh data tentang pernikahan dini akibat putus sekolah sebanyak 23 orang dengan rincian kambeng Utara 5 anak (21,74\%), Bunbeleng 4 anak (17,39\%), Menomang 4 anak (17,39\%), Kambeng 3 anak (13,04\%), Kambeng Timur 3 anak (13,04 $\%)$, Kambeng Barat 2 anak (8.70\%), aik Mual 1 anak (4,35 \%) dan telage lindung 1 anak ( 4,35 \%)Data awal Kegiatan sosialisasi dampak putus sekolah dilaksanakan berdasarkan jadwal dan undangan yang diberikan kepada peserta. Kegiatan ini berjalan dengan baik dan lancar sesuai target kegiatan. 
Selanjutnya dilaksanakan kegiatan sosialisasi yang diwakili oleh anak-anak yang berasal dari sepuluh dusun, masing-masing kadus diwakili oleh 2 anak yang telah ditunjuk bersama-sam dari pihak pengabdi, kadus, pihak desa dan ketua KPAD selanjutnya disepakati waktu dan tempat pelaksanaan yaitu hari sabtu tanggal 30 september 2017 bertempat di AULA Diniyah Hikmatul Falah Jelateng sekotong Timur Lembar sedangkan narasumber diserahkan sepenuhnya kepada pengabdi.

Kegiatan Sosialisasi dimulai dengan acara pembukaan yang diikuti oleh peserta , pengabdi, wakil dari Desa dan narasumber.

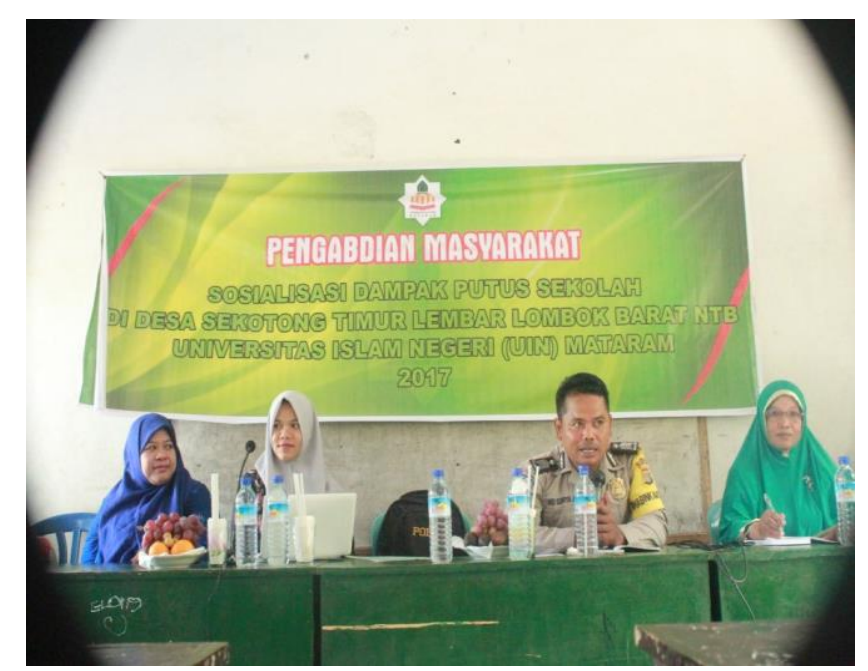

Kegiatan pembukaan diawali dengan kata sambutan dari pengabdi. Pengabdi memberikan gambaran tentang pentingnyasosialisasi dampak putus sekolah bagi anak-anak di desa Sekotong Timur Lembar Lombok Barat. Pengabdi menjelaskan bahwa dengan memberikan sosialisasi tentang dampak putus sekolah maka nak-anak akan terkuak cakrawalanya tentang pentingnya pendidikan dan menuntut ilmu karena dengan ilmu pengetahuan yang diperoleh di bangku sekolah berguna untuk meningkatkan sumber daya manusia sebagai bekal di masa depan Selain itu, pengabdi juga sekedar mengingatkan peserta yang hadir bahwa Institut Agama Islam Negeri ( IAIN ) Mataram sudah resmi berubah status menjadi sebuah universitas yakni Universitas Islam Negeri Mataram ( UIN Mataram). Hal ini bisa membawa angin segar bagi kalangan akademisi di UIN Mataram dan bisa dimungkinkan 
bahwa kegiatan sosialisasi serupa atau kegiatan pengabdiandalam peningkatan motivasi belajar anak-anak bisa diselenggarakan di tempat dan peserta yang sama atau dalam ruang yang lebih luas di masa mendatang. Pernyataan pengabdi ini disambut tepuk meriah dan senang oleh para peserta.

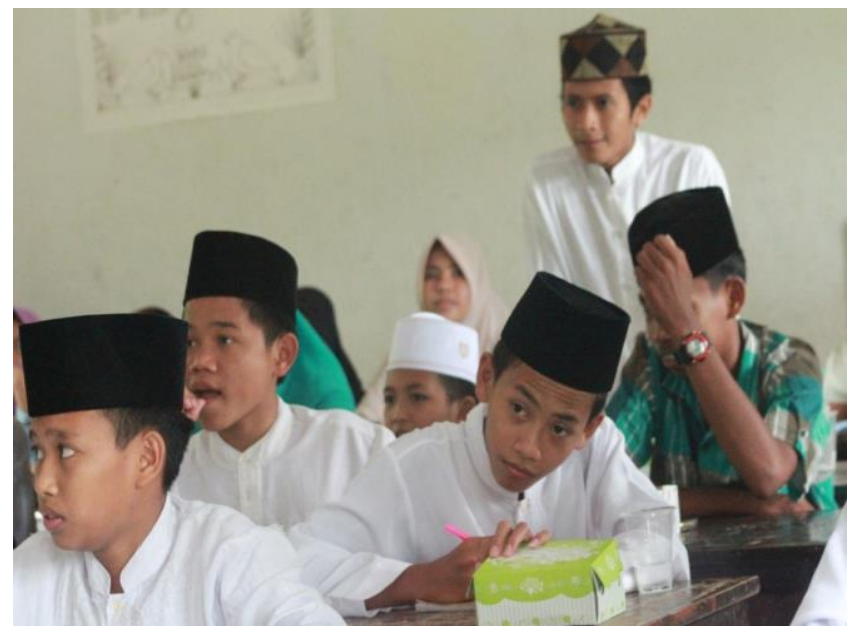

Setelah pengabdi menyampaikan sepatah kata, dilanjutkan oleh wakil dari desa Sekotong Timur Lembar dalam hal ini diwakili oleh Bapak Zohri, S.Pd Beliau menyampaikan beberapa hal dan sekaligus membuka acara kegiatan sosialisasi dampak putus sekolah desa Sekotong Timur Lembar Lombok Barat, beliau berharap bahwa kegiatan ini bisa membawa angin segar bagi anakanak dan orang tua agar memiliki motivasi belajar yang tinggi dan bisa memberikan informasi kepada keluarganya dan teman sebayanya tentang pentingnya sekolah dan menuntut ilmu sebagai bekal di masa depan. Beliau juga menyampaikan dan berharap agar pihak UIN mataram melaksanakan kegiatan serupa di desa Sekotong Timur guna membina anak-anak dan bekerja sama dengan pihak des, a dusun dan masyarakat dalam membangun sumber daya manusia terutama anak-anak dan generasi muda desa Sekotong Timur karena semenjak maraknya penambangan emas tradisional terjadi banyak anak-anak yang putus sekolah lalu menikah di usia dini. Beliau sangat bersyukur dan berterima kasih kepada pihak UIN mataram yang telah memfasilitasi kegiatan sosialisasi dampak putus sekolah ini semoga pada 
waktu yang lain bisa melaksanakan tema tema actual dalam melakukan pembinaan di Desa Sekotong Timur.

Pada kesempatan itu pula, Bapak Zohri, S.Pd menyampaikan salam dari Bapak Kepala Desa yang berhalangan hadir karena ada kegiatan di luar kota, Beliau menyampaikan terimakasih kepada pengabdi atas pilihannya di Desa Sekotong Timur Lembar sebagai sasaran dan subjek pengabdiannya.

Setelah dibuka dengan resmi oleh Bapak Zohri, S.Pd, kegiatan sosialisasi dilanjutkan dengan dialog antara pengabdi wakil dari desa dan narasumber. Kegiatan dialog ini dimaksudkan untuk mengetahui kemampuan pengetahuan peserta sosialisasi tentang dampak putus sekolah dan seberapa besar motivasi belajar mereka, para peserta sosialisasi sangat antusias dengan dialog ini beberapa diantara mereka mengacungkan tangan untuk menyampaikan pendapat mereka satu persatu lalu bagi peserta yang memberanikan diri menyampaikan pendapat diberikan hadiah alat tulis dari pihak desa dan pengabdi guna merangsang motivasi dan antusiasme bagi peserta sosialisasi yang lain yang belum berkesempatan menyampaikan pendapatnya.

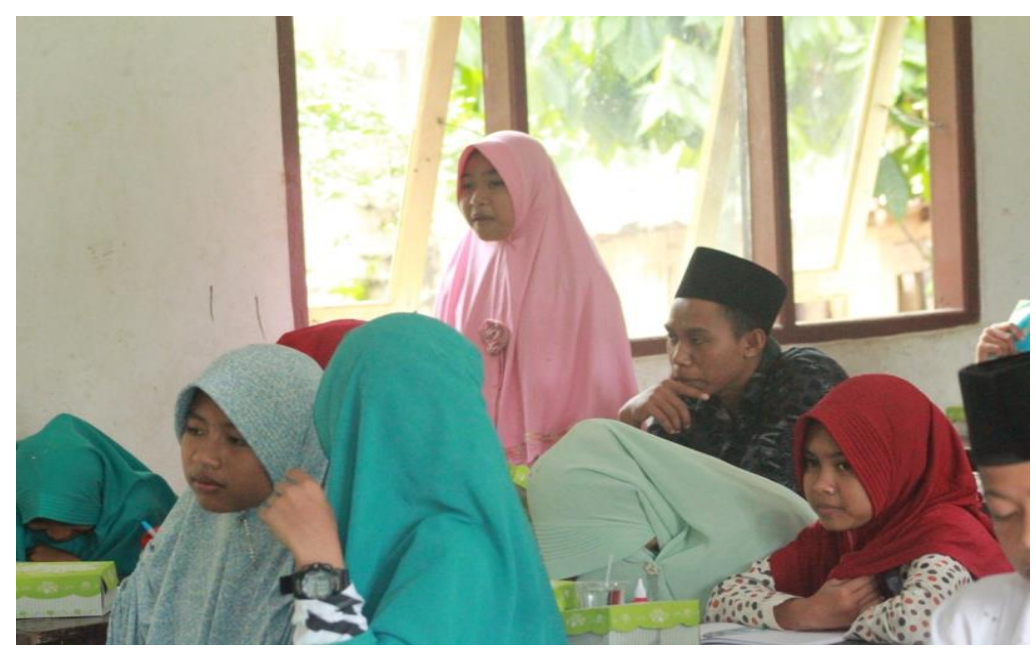

Acara selanjutnya coffe break, dimana para peserta sosialisasi beristirahat sejenak sambil menikmati snack atau kue-kue yang disediakan oleh panitia. 
Pada sosialisasi ini, narasumber Bapak H. Muhammad Abu Arif Aini, S.Ag, M.Pd Beliau membawakan materi tentang dampak putus sekolah beliau mengawalinya dengan menyampaikan bahwa Masa remaja, masa yg rentan dan berbahaya, labil, secara psikologis ingin mengetahui segala hal. QS.AlBaqarah ayat 102 menerangkan tentang dampak dari khamar, penyalahgunaan narkoba pergaulan bebas mencuri dan membegal.Dampak putus sekolah, memilih teman yg sama, menjadi gelandangan, mudah terbawa arus perkembangan dan kemajuan zaman. Sehingga untuk mengantisipasi dampak-dampak negativ lain, maka mau tidak mau jalan yang terbaik adalah dengan terus bersekolah dan terus belajar, menuntut ilmu.

Narasumber lebih lanjut menyampaikan bahwa melanjutkan sekolah dibutuhkan motivasi belajar yang tinggi dengan cara bergaul dengan teman sebaya yang baik, rajin dan memiliki akhlak dan peringai yang sopan. Alangkah baiknya jika anak-anak menuntut ilmu di pondok pesantren terdekat dengan sekolah jika biaya kurang memadai, beliau menyampaikan bahwa pihak kemenag memvasilitasi diniyah-diniyah dan pondok pesantren baik berupa sumber daya sarana prasarana, sumber daya manusia dan sumber daya yang lain guna membantu proses pembelajaran anak-anak di sekolah swasta maupun sekolah-sekolah negeri jadi tidak ada halangan dan alasan bagi anak-anak untuk tidak sekolah. Bagi anak-anak kurang mampu dan berprestasi kemenag juga menyediakan beasiswa dan penghargaan bagi anak-anak tersebut.

Lebih lanjut beliau memberikan dorongan kepada peserta sosialisasi dampak putus sekolah dengan menceritakan kisah-kisah para nabi sebagai suri tauladan dalam menuntut ilmu dan kisah-kisah orang-orang sukses dalam belajar dan masa depan, beliau mengatakan bahwa kesuksesan seseorang tidak didukung seratus porsen karena pengaruh kecerdasan tapi masih banyak faktor lain yang mendukung kesoksesan tersebut seperti motivasi belajar, gaya belajar, ketekunan dan pergaulan. Jadi jika ingin menjadi anak yang berhasil dan sukses maka anak-anak harus bergaul dengan teman sebaya 
yang baik, rajin, memiliki motivasi belajar yang tinggi dan memiliki cita -cita yang sesuai dengan keterampilan dan kemampuan.

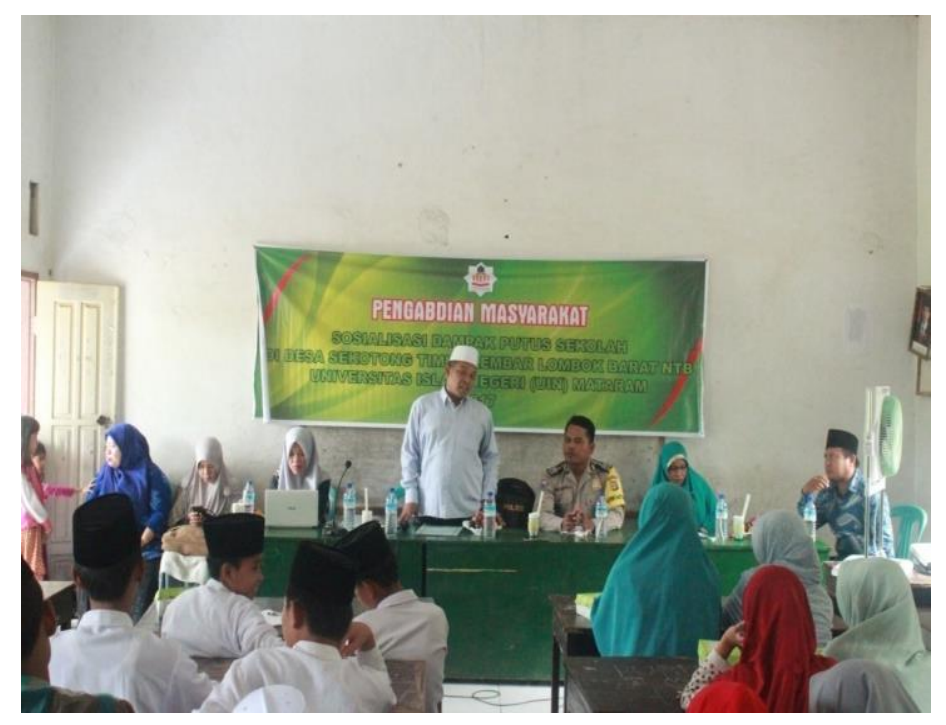

Materi yang dibawakan oleh Bapak Muhammad Abu mendapat perhatian yang sungguh-sungguh dari seluruh peserta. Hal ini bisa terlihat dari antusias peserta sosialisasi dalam memberikan pertanyaan kepada Bapak Abu, baik pertanyaan mengenai cara meningkatkan motivasi belajar, cara memilih teman bergaul, cara mendapatkan beasiswa sekolah dan menghindari pergaulan bebas agar tidak terjadi putus sekolah. Sesekali peserta mencoba memberikan idenya terhadap upaya-upaya agar tidak putus sekolah lalu peserta lain bertepuk tangan kegirangan karena mendapatkan masukan dari kawannya sendiri dan dijelaskan kembali oleh narasumber.

Bapak H. Muhammad Abu Arif Aini S.Ag, M.Pd menutup materi dengan pernyataan beliau bahwa untuk berhasil dalam bangku sekolah dan tidak putus sekolah, anak-anak harus menjagapergaulan, harus memiliki motivasi belajar yang tinggi disiplin waktu berbakti kepada orang tua dan berdoa. Dengan menjaga pergaulan dan motivasi belajar yang tinggi, bukan sesuatu yang mustahil anak akan mencapa prestasi yang gemilang dan tentunya tidak putus sekolah. Pernyataan tersebut disambut dengan tepuk tangan yang gemuruh dari para peserta. 


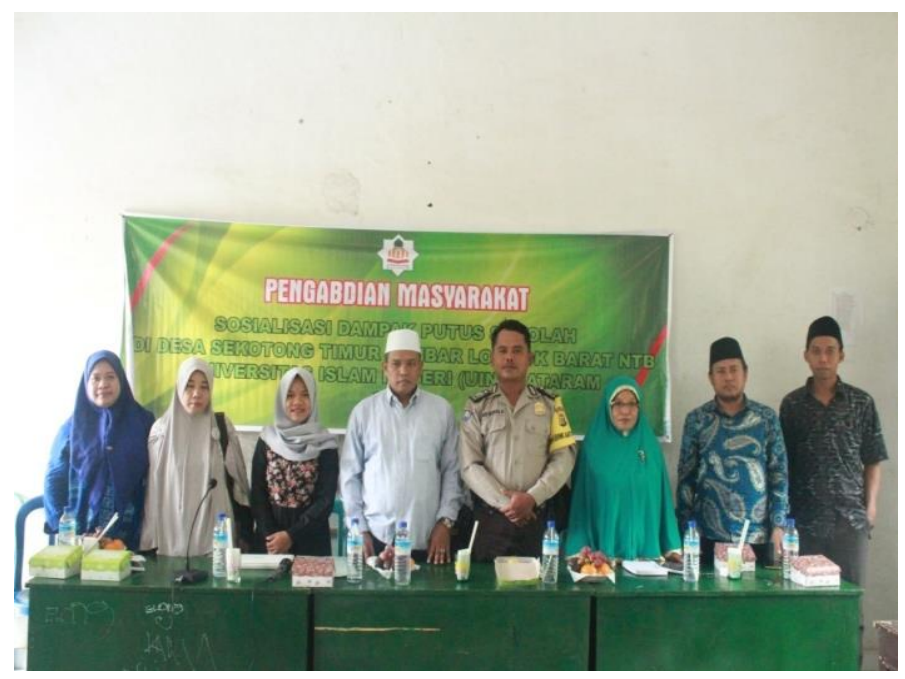

Setelah berakhirnya materi, pengabdi menutup acara dengan mengucapkan terimakasih atas partisipasi peserta dalam acara sosialisasi dampak putus sekolah serta panitia dan Bapak Zohri, S.Pd. yang telah memberikan dukungan yang cukup besar terhadap kelancaran dan kesuksesan kegiatan. Selanjutnya peserta narasumber panitia, pihak des dan Ketua KPAD beramah tamah sambil sesekali berbincang tentang tindak lanjut kegiatan ini.

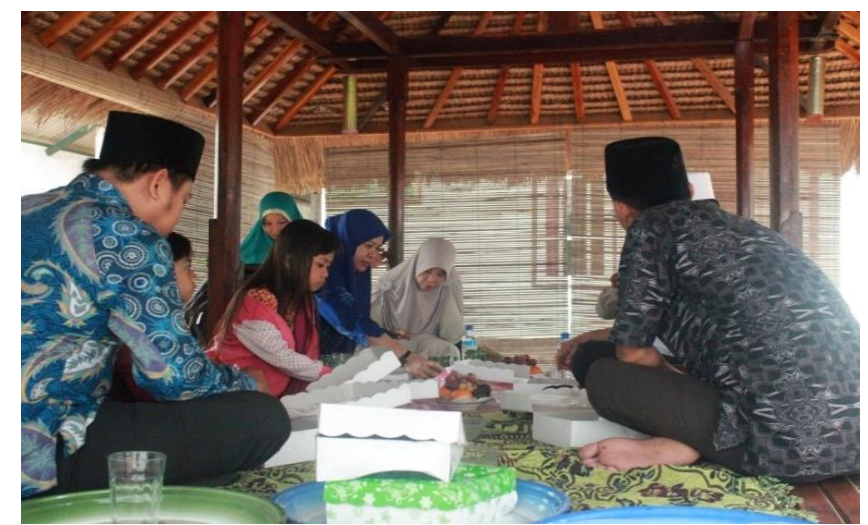

Sehari setelah kegiatan sosialisasi dampak putus sekolah dilaksnakan pengabdi, wakil dari desa dan ketua KPAD mengadakan pertemuan dengan semua kadus guna membentuk tim mentor pendampingan dan penanggulangan dampak putus sekolah di masing-masing dusun dan bekerja sama dengan KPAD sehingga terbentuklah mentor pendampingan dan penanggulangan dampak putus sekolah terutama pernikahan dini. 
Transformasi, Vol. 13, No. 2, Juli 2017:208-218

\section{KESIMPULAN}

Kesimpulan yang dapat diuraikan pada kegiatan sosialisasi dampak putus sekolah di Desa Sekotong Timur adalah:

1. Faktor yang menyebabkan terjadinya putus sekolah di Desa Sekotong Timur Lembar Lombok Barat NTB adalah faktor ekonomi masyarakat yang rendah, minat anak yang kurang untuk bersekolah, fasilitas kurang, ketiadaan sekolah, perhatian orang tua, serta faktor budaya setempat.

2. Kegiatan sosialisasi yang diselenggarakan di Desa Sekotomg Timur berdampak positif bagi anak-anak putus sekolah dalam memacu semangat untuk melanjutkan sekolah serta semangat untuk menggapai masa depan yang lebih baik.

Harapan masyarakat terhadap kegiatan ini adalah keberlanjutan dan kekontinyuan dalam memberikan pemahaman dan pengetahuan yang baik bagi orang tua dan masyarakat dalam mencegah putus sekolah.

\section{DAFTAR PUSTAKA}

http://makalahplus.blogspot.co.id/2015/06/faktor-penyebab-terjadinya-anakputus-sekolah.html

http://jurnalilmiahtp2013.blogspot.co.id/2013/12/penyakit-putus-sekolah.html http://yudi-wiratama.blogspot.co.id/2014/01/putus-sekolah.html http://makalahcentre.blogspot.co.id/2011/01/anak-putus-sekolah.html https://imeducation.wordpress.com/2013/06/25/dampak-dari-anak-yang-putussekolah/ 